\title{
Disagreement practices in ELF academic group discussion: Verbal, non- verbal and interactional strategies
}

Anuchit Toomaneejinda

Luke Harding

Lancaster University

Authors' post-print version. Toomaneejinda, A. \& Harding, L. (to appear September, 2018).

Disagreement practices in ELF academic group discussion: Verbal, non-verbal and interactional strategies. Journal of English as a Lingua Franca.

Abstract: Academic group work can involve challenging pragmatic acts, and chief among these is, arguably, disagreement. There is little known, however, about how disagreement is realised in ELF academic group discussion tasks, where the tendency towards greater cooperation and mutual support in ELF communication (see Seidlhofer, 2001) may be at odds with the need to achieve task goals through the expression of an oppositional stance. In addressing this issue, the current study sought to answer the research question: how do postgraduate students in a UK university setting express their disagreement in ELF academic group discussion? Twelve participants from ten different linguacultural backgrounds completed two different simulated discussion tasks: one targeting opinions, and the other consensus decision-making. The same participants also took part in retrospective stimulated-recall interviews using the videorecording of their discussions as a stimulus. Discourse analysis of the transcribed interactions revealed that the ELF participants used a wide range of verbal, non-verbal and interactional strategies in their disagreeing practices. Three salient strategies are presented in detail: focus shifts, complex turn-management (other-initiated disagreement turn dependence and turnthrowing/passing), and the use of gaze. Through these examples, we show that while the discourse produced in group discussion tasks was rich in disagreement, ELF participants used complex linguistic and interactional strategies to avoid explicit displays of their oppositional stance. Results are discussed with a view to developing theory around disagreement in ELF academic contexts. 
บทคัดย่อ: การทำงานกลุ่มของนักศึกษานั้นต้องอาศัยการแสดงเจตนาต่างๆ

โดยเฉพาะอย่างยิ่งการแสดงการไม่เห็นด้วย

อย่างไรก็ตามที่ผ่านมามีงานวิจัย ไม่มากนักที่ศึกษาวิธีการแสดงการไม่เห็นด้วยในการอภิปรายกล่่มของนั กศึกษาที่ใช้ภาษาอังกฤษในฐานะภาษากลาง

ซึ่งการแสดงการไม่เห็นด้วยนี้อาจจะมีความ ไม่สอดคล้องกันกับงานวิจัยก่อนหน้านี้ที่อ้างว่า

การสื่อสารโดยการใช้ภาษาอังกฤษในฐานะภาษากลางมักจะเน้นที่การให้ความร่วมมือและสนับสนุนซึ่งกั นและกันของผู้ใช้ภาษา (Seidlhofer, 2001)

ในขณะที่การแสดงการไม่เห็นด้วยกลับเป็นปัจจัยสำคัญที่ทำให้การอภิปรายกลุ่มสำเร็จลุล่วงไป คำถามวิจัยหลักของบทความวิจัยนี้คือ

นักศึกษาต่างชาติระดับปริญญาโทที่ศึกษาในประเทศสหราชอาณาจักรแสดงการไม่เห็นด้วยในการอภิปร ายกลุ่มอย่างไร เพื่อตอบคำถามวิจัยดังกล่าวนักศึกษาระดับปริญญาโทจำนวน 12 คนจาก 10 ประเทศได้เข้าร่วมการอภิปรายกลุ่ม 2 ครั้ง ครั้งแรกเพื่อแลกเปลี่ยนความคิดเห็นทั่วไป ส่วนครั้งที่สองนั้นเพื่อร่วมหาข้อยุติในประเด็นที่กำหนดให้ โดยการเข้าร่วมการอภิปรายกลุ่มดังกล่าวได้มีการบันทึกวิดีทัศน์ไว้ทั้งหมด จากนั้นนักศึกษาจำนวน 12 คนดังกล่าวได้รับเชิญให้เข้ามารับการสัมภาษณ์ โดยนักศึกษาได้ดูและอธิบายการมีปฏิสัมพันธ์ที่มีการบันทึกวิดีทัศน์ไว้ของตนเอง ซึ่งผลการวิเคราะห์ถ้อยความเผยให้เห็นว่า ในการแสดงการไม่เห็นด้วยนั้น นักศึกษามีวิธีการที่หลากหลายทั้งวัจนภาษา และอวัจนภาษา รวมไปถึงการใช้กลวิธิในการมีปฏิสัมพันธ์ต่างๆ โดยในบทความวิจัยนี้ได้นำเสนอกลวิธีที่โดดเด่น 3 กลวิธี ได้แก่ การเบี่ยงหรือการเปลี่ยนประเด็น การผลัดการสนทนาที่มีความซับซ้อน (การอาศัยการไม่เห็นด้วยของคู่สนทนา และการโยน/การส่งผ่านผลัดการสนทนา) และการใช้การเพ่งมอง จากตัวอย่างต่างๆ ในบทความวิจัยนี้แสดงให้เห็นว่า ในการแสดงการไม่เห็นด้วยในกลุ่มอภิปรายของนักศึกษานั้น นักศึกษาได้เลือกใช้กลยุทธ์ต่างๆ ที่มีความซับซ้อน ทั้งตัวภาษาและวิธีการมีปฏิสัมพันธ์ ทั้งนี้เพื่อหลีกเลี่ยงการแสดงจุดยืนที่แตกต่างของตนเองอย่างชัดเจน อนึ่ง ผลวิจัยที่รายงานนี้เป็นข้อมูลเพื่อการต่อยอดเชิงทฤษฎิในการอธิบายการแสดงการไม่เห็นด้วยในบริบทที่ มีลักษณะเฉพาะอย่างในบริบทมหาวิทยาลัยที่ใช้ภาษาอังกฤษในฐานะภาษากลาง

Key words: disagreement, academic group discussion, English as a lingua franca, disagreeing practices 


\section{Introduction}

Academic group discussion is a common feature of learning within higher education (HE) contexts, particularly at the postgraduate level where seminar teaching provides space for inclass group-work and where assessment tasks might be completed collectively (Jones, Connolly, Gear, \& Read, 2006; Wisker, Robinson, \& Shacham, 2007). Group discussion may be a method of brainstorming, planning, or exchanging opinions. As such, group discussion can be linguistically complex, with interactants required to share their own ideas and potentially challenge the ideas of others while maintaining a good working relationship (Beccaria, Kek, Huijser, Rose, \& Kimmins, 2014). The complexity is heightened by the linguacultural diversity of an increasingly international student body. Academic group discussion across many EMI programs can be characterised as a key site of English as a lingua franca (ELF) communication. Group discussion in such contexts requires a set of verbal and interactional skills - conflict- or problem-solving ability and communicative strategies - which take into account interlocutors from a range of linguistic and cultural backgrounds (Jones, 1999; Mauranen, 2012).

One of the most challenging communicative acts to perform within such contexts is, arguably, disagreement. While disagreement might be crucial within a discussion task for critiquing competing ideas, obtaining a consensus, and completing a task, it is also potentially a face-threatening communicative act which can disrupt the social equilibrium of a group. A small but growing number of studies have begun to explore disagreement practices within general ELF contexts (Jenks 2012, 2017; Pietikäinen 2018) and within the specific domain of HE (e.g., Björkman, 2015, 2017; Konakahara, 2017). Three studies in particular have explored the unique nature of disagreement in multi-party discussion within ELF academic settings (Bjørge, 2016; House, 2008; Konakahara, 2016). However, no study to date has combined analysis of verbal and non-verbal disagreeing practices within polyadic ELF academic discussion with participants' meta-pragmatic comments on the same interaction. In this paper we explore the ways in which disagreement is realised in academic group discussion through a multimodal analysis of discourse produced by two groups performing two different discussion tasks in a simulated environment, drawing on participants' meta-pragmatic comments gathered through a stimulated recall interview to triangulate findings. We map out specific verbal, non-verbal and interactional practices in realising disagreement within the simulated discussions, drawing implications for theorising disagreement within ELF contexts, and within academic group discussion in particular. 


\section{Disagreement}

Disagreement is related to concepts such as oppositional talk (Bardovi-Harlig \& Salsbury, 2004), conflict talk (Grimshaw, 1990; Gruber, 1998; Hammer, 2005; Honda, 2002) opposition (Kakavá, 2002), arguing (Muntigl \& Turnbull, 1998), and antagonism (Tannen, 2002). A basic definition can be drawn from Rees-Miller's (2000) study, where disagreement is said to be produced when a speaker "considers untrue some Proposition P uttered or presumed to be espoused by an Addressee A and reacts with an utterance the propositional content or implicature of which is not P" (p. 1088). By perceiving disagreement as an utterance, Rees-Miller's definition appears to include only those instances where differing opinions are expressed verbally. In this more restricted view, a disagreement is seen to comprise at least two related turns: a disagreement source turn (the original utterance to which the disagreement corresponds, which could be directly previous to that utterance or further back in the conversation, and may be spread over multiple turns), and a disagreement-responding turn. A simplified example - illustrating a very direct disagreement - is shown below:

A: This is a wonderful wine $\longrightarrow$ 'disagreement source turn'
we're drinking.

B: $\quad$ No it's disgusting. $\quad \longrightarrow \quad$ 'disagreement responding turn'

A broader definition, however, recognises that disagreement may be expressed both verbally and nonverbally, through gaze, facial expressions, head moves, smiles/laughter, and gesture (Bousmalis, Mehu \& Pantic, 2013) as well as through silence (Schegloff 1968, Pomerantz 1975, Pietikäinen 2018). Kakavá's (2002) definition, for example, captures this wider view in characterising disagreement as an oppositional stance or reaction - either verbal or nonverbal which "involves the negation of a stated or implied proposition" (p. 1539). Disagreement in the current study is also broadly defined as an interactant's response or reaction to an interlocutor's previous utterance to show his or her opposing stance or opinion. This definition is suitable for multi-party interactional settings as it covers situations in which participants agree with, or rely on, other-initiated disagreement to convey their differing opinions, or in cases where oppositional alliances are formed (Kangasharju, 2002).

Disagreement has generally been portrayed as a negative communicative act. For example, Locher (2004) argues that disagreement deals with the exercise of power and a clash of interests and can trigger a form of confrontation which, according to Kakavá (1993), may lead to 
dispute and, ultimately, to conflict. From the perspective of Conversation Analysis (CA), Pomerantz (1984) argues that because disagreement can be discomforting, threatening or offensive to interlocutors, it is dispreferred in conversation (see also Sifianou, 2012). Research has shown that disagreement is often realised through less direct pragmatic functions (e.g., challenges, partial agreement) and with mitigation used to modify the strength of the communicative intent (Gruber, 1998; Kakavá, 1993; Kotthoff, 1993; Kreutel, 2007; Muntigl \& Turnbull, 1998; Pomerantz, 1984; Stalpers, 1995). Agreement, by contrast, can be expressed more directly as it builds up a comfortable, sociable atmosphere indicating interlocutors' supportiveness and like-mindedness. However, in certain social situations, disagreement may be deemed necessary, and is preferred, since it can help to strengthen relationships and increase active participation within a group (see Angouri, 2012), an observation which has been extended to academic discussion contexts (see Björkman, 2015; Mauranen, 2012). Pomerantz (1984), for instance, asserts that disagreement in the form of a self-deprecating response to a compliment is preferred, particularly when it is performed in an overt and immediate manner. Schiffrin (1984) also argues that disagreement among friends could enhance sociability instead of being the cause of a breach of civility. Across a number of studies, disagreement has been observed to be a sign of familiarity, intimacy and solidarity (Georgakopoulou, 2001; Kakavá, 1993; Locher, 2004; Tannen, 1984).

\section{Disagreeing in ELF academic settings}

Within academic contexts, Izadi (2013) and Leech (2014) argue that disagreement is indispensable in genres of speech such as dissertation defences, departmental meetings, seminars, symposia or group meetings, since it helps to extend disciplinary knowledge and enhance interactants' professional status. However, the role of disagreement within ELF academic settings raises a unique issue. ELF speakers are thought to be aware of, and to prepare for, communication breakdown, and tend to use and transform available linguistic and nonlinguistic resources for this purpose (Cogo, 2010; Dewey, 2007; Firth, 2009; Kaur, 2009; Mauranen, 2012). Interactions in ELF contexts are therefore generally thought to be inherently “consensus-oriented, cooperative, and mutually supportive" (Seidlhofer, 2001, p. 143). However, recent ELF research reveals that ELF is not always cooperative and agreement-oriented (Jenks, 2012, 2017; Pietikäinen, 2018) and that there is a lack of research on conflict/oppositional talk in ELF studies. For example, ELF interactants have been shown to interact using extensive and strong disagreement (Konakahara, 2016), and to engage in joking, laughter and ridicule (Jenks, 2012; Kappa, 2016). Kappa (2016) has argued that early ELF research appeared to marginalise 
conflict talk and oppositional or disaffiliative interactions, and purported the erroneous belief that ELF speakers would interact the same across all communicative contexts. Ehrenreich (2017) concurs, stating that ELF communities of practice (CoPs), like other CoPs, can be cooperative or conflict driven. The "orthodoxy" that ELF is cooperative and agreement-oriented arguably oversimplifies the complex nature of human interactions since it overlooks individual differences and the influence of prior experience and current contexts on interactional practices.

It is clear, therefore, that researching oppositional talk within ELF academic discussions is important for the purposes of (a) discovering more about how disagreement functions in ELF environments, and (b) building theory with respect to the nature of oppositional talk in ELF settings. However, while there have been some studies which have explored disagreement within ELF academic environments (e.g., Björkman's, 2015 and 2017 studies of PhD supervisory meetings), few have focused on academic group discussion. House (2008) considered disagreement within an academic group meeting, noting that there was a high degree of direct disagreement among ELF participants. By contrast, Bjørge (2012) found in a comparative study of the language produced by upper intermediate/advanced level business students in simulated ELF business negotiations that ELF students used predominantly mitigated disagreement. In perhaps the closest study to the current investigation, Konakahara (2016) investigated disagreement in casual conversation between groups of international students in British universities. Her study revealed that participants produced both direct and indirect disagreement and that the communicative act of disagreement is a dispreferred next action, conforming to previous findings related to preference organization (Pomerantz, 1984).

While these studies have increased our understanding of the nature of disagreement in ELF academic group discussion, participants' meta-pragmatic comments have not been included as a data source (with Björkman [2017] a notable exception). For example, House (2008) and Bjørge (2012) drew primarily on corpus-based discourse analytic methods, while Konakahara (2016) adopted a conversation analytic approach. There is room, however, to draw on interactants' views to support interpretations, particularly in light of a general shift in politeness research from more static principle-based approaches to the "relational work" perspective suggested by Locher and Watts (2008). Relational work classifies interactional behaviours in a more detailed manner with respect to an appropriate norm within a certain interactional environment (Locher, 2006). In this regard it is important to consider not only the verbal or nonverbal behaviour observable through discourse, but to also seek interactants' perspectives on linguistic forms and their appropriateness to the interaction. This study, therefore, draws on a multiple-method approach to reveal in greater depth some key practices which were used by ELF interactants to express disagreement in simulated academic group discussion. 


\section{Data and methodology}

\subsection{Data and participants}

The data presented in this study were drawn from transcriptions of 117-minutes of recorded simulated group discussion, and 24-hours of stimulated recall interviews, involving MA students studying in a linguistics department at a UK university.

Twelve participants were recruited from a non-credit MA-level course which is designed to support postgraduate students in developing academic writing and learning skills. This course runs parallel to their linguistics modules throughout the academic year. Participants were purposefully selected from a larger pool so as to make up two groups of speakers from different linguacultural backgrounds and levels of English language proficiency. The details of participants in the two groups are shown in Table 1.

Table 1. Participant details

\begin{tabular}{cccccc}
\hline & \multicolumn{2}{c}{ Group 1 } & & \\
\hline Pseudonym & Nationality & First language & Gender & Age & IELTS score \\
\hline Lexie & Cypriot & Greek & F & 21 & 7.5 \\
Jiro & Japanese & Japanese & M & 33 & 8.0 \\
Caroline & Dutch & Dutch & F & 22 & 8.5 \\
Nourah & Saudi Arabian & Arabic & F & 22 & 6.5 \\
Haeun & Korean & Korean & F & 25 & 6.5 \\
Mei & Chinese & Mandarin Chinese & F & 24 & 6.5
\end{tabular}

\section{Group 2}

\begin{tabular}{cccccc}
\hline Pseudonym & Nationality & First language & Gender & Age & IELTS score \\
\hline Jimmy & British & English & M & 51 & Not available \\
Unyil & Indonesian & Bahasa Indonesia & M & 25 & 7.0 \\
Sukura & Japanese & Japanese & F & 34 & 7.0 \\
Roxane & Swiss & Swiss German & F & 23 & 8.5 \\
Yoonsuh & Korean & Korean & F & 44 & 7.5 \\
Catalina & Chilean & Spanish & F & 29 & 7.5 \\
\hline
\end{tabular}




\subsection{Discussion tasks}

Following a two-week period of observation in the academic studies skills course described above, two tasks were designed to form the basis for group discussions inspired by discussion tasks used during the class. The tasks were designed to simulate situations in which disagreement would be more or less crucial for completing a discussion activity successfully. Task A consisted of a set of general opinion- or experience-based topics, such as "British politeness", and "Coursework assignments". There was an expectation that in Task A discussions, disagreements may emerge naturally, but were not crucial to task completion. Task B was designed to be more disagreement-oriented. In this task participants simulated a meeting to determine funding allocations for student-led projects. The group had a budget, and the combined cost of listed projects exceeded this budget. Therefore, participants had to determine in advance which projects should be given priority, to defend their choices and to reach a consensus.

We note the limitation that using simulated tasks may have resulted in discussions where disagreement was not as high-stakes as it would be in an authentic context. For example, in "reallife" ELF settings where speakers would be expected to share a common goal (such as an authentic academic group discussion task), there is a shared responsibility among participants to fulfil a task within time constraints, which may lead to a greater number of disagreements, or to more direct disagreements. The consequences of not completing the task adequately were less serious in the simulated condition. However, the simulated task allowed for a method of data collection in which video-recordings were clear, audio was intelligible, and where tasks could be controlled for length, all of which were crucial for ensuring the feasibility of the stimulated recall procedure (which was already considerably time-intensive for the participants). Further, participants were asked to indicate how authentic they felt the task to be in a post-hoc questionnaire, and unanimously concurred that they acted naturally throughout the task. In using simulated tasks, we follow other research (e.g., Bjørge, 2012) which has found simulated discussion to be rich sites for observing disagreement practices. We also acknowledge that the participants were all from the same discipline- Linguistics - and that another course or setting may have revealed other types of disagreement practices.

\subsection{Data collection procedure}

Data in this study consisted of (1) recorded (audio and video) group discussions, which were transcribed and analysed for linguistic disagreement realisation practices, and (2) stimulated recall interviews conducted with individual participants following each group discussion. 


\subsubsection{Group discussions}

Participants were invited to take part in simulated group discussions in a quiet classroom on the university campus. Each group (Group 1 and Group 2) completed both discussion tasks in two separate sessions, with the order of tasks counter-balanced across the groups (see Table 2).

Table 2. Order of tasks

\begin{tabular}{ccc}
\hline & Time 1 & Time 2 \\
\hline Group 1 & Task A & Task B \\
Group 2 & Task B & Task A \\
\hline
\end{tabular}

Each discussion was started by an independent moderator who explained the task instructions and invited the groups to begin talking. In all other respects, the discussions were allowed to develop naturally. Recording of each session was captured by two audio recorders placed on the table, and four video recorders placed outside the perimeter of chairs so as to capture all of the participants. Video recording of the interactions played three vital roles in the study: (1) it enabled analysis of non-verbal disagreement realisations; (2) it provided a stimulus for the stimulated recall interview (see below); and (3) it supported accurate transcription of the multiparty talk. Each group discussion lasted between 24 and 36 minutes, after which participants completed a brief questionnaire designed to gather their perceptions of the interactions.

\subsubsection{Stimulated recall interviews}

Participants were invited to attend stimulated recall interviews within three to seven days following the group discussions. These interviews were designed to elicit participants' metapragmatic comments on their disagreement practices (Gass and Mackey, 2000; SpencerOatey, 2013). The time delay was necessary as it was important to develop first-draft transcriptions of the data, summarise the questionnaire responses and locate initial instances of disagreement in the data. While the length of delay may have resulted in memory decay, accuracy of recall would still be expected range from between $82.5 \%$ - 92.5\% according to Bloom (1954). The stimulated recall method used in this study can be characterised as jointly participant- and researcher-led. Participants were asked to watch a recording of their most recent group discussion session and to pause the video whenever they wanted to talk about the thoughts or intentions underlying the interactional practices they were observing. The researcher also paused the video and asked specific questions at certain points in the interaction which had been 
identified as disagreement episodes in an initial analysis of the discourse. Interviews were audiorecorded for later transcription. This process was conducted for every participant after each group discussion session. Stimulated recall interviews typically lasted 60 minutes each time, thus the final set of stimulated recall data ran to approximately twenty-four hours.

\subsection{Data analysis}

Group discussion data (approximately 117 minutes) was transcribed (by Author A; with a random sample checked by Author B) based on a scheme developed by Du Bois, Schuetze-Coburn, Cumming and Paolino (1993) and adapted for the specific needs of the study. Transcription conventions are shown in Appendix 1. Transcripts were analysed in ATLAS.ti using an iterative process in which categories emerged from the data, and were cross-referenced to relevant literature (e.g., Muntigl \& Turnbull, 1998). Coding of disagreement instances and types was initially performed by the first author together with a team of three experienced coders, where $90 \%$ agreement was reached. A second stage of coding was conducted with the second author, where initial coding was re-checked, and problematic instances were discussed and decided upon. Data from the stimulated recall interviews were transcribed using a broader system concentrating on content. A thematic analysis (Braun \& Clarke, 2006) was then conducted in a similar way to the coding of disagreement instances in the group discussion data. For the purposes of this paper, data from the stimulated recall interviews will only be drawn upon to triangulate points of analysis. A full discussion of the thematic analysis is provided in Author 1 (2018).

\section{Data analysis}

\subsection{Overview of findings}

There were 200 instances of disagreement identified across all group discussion data. 158 were instances of verbal disagreement, while 42 were nonverbal expressions of disagreement, identified and verified through participants' self-reports during the stimulated recall interview. Within identified instances of verbal disagreement, the great majority (60\%) were classified as "Focus shifts", a disagreeing practice in which a speaker makes an alternative claim in response an interlocutor's proposition (see Georgakopoulou, 2001; Gruber, 1998; Osvaldsson, 2004). Other practices observed, to lesser extents, were "Statements of the opposite" (17\%), which comprised basic contradictions, "Rhetorical questions" (9\%), "Abrupt topic change" (5\%) or "Combinations" $(6 \%)$ of different practices. Almost all instances were classified as "non- 
performative" disagreement, in which oppositional stance is expressed indirectly. Only two examples of speakers using the performative verb "disagree" (or not + agree) were observed in the data, providing evidence that direct, performative disagreement was unusual and thus a dispreferred activity. Within these different categories, speakers used a range of mitigation devices to delay disagreement within a turn such as pauses, hedges and prefaces, as well as posthoc apologies following the expression of disagreement. Speakers also delayed turns by using turn-waiting, turn-throwing/passing, and other-initiated turn-dependence and made use of nonverbal signals such as gaze, facial expressions, and posture to manage disagreement episodes within the multi-party talk. In several cases, participants reported that they maintained silence rather than disrupt the equilibrium of the group, or their place within it, with an overt disagreement.

The general findings of the analysis (reported in detail in Author 1, forthcoming) built-up a picture of disagreement practices in ELF academic discussion as a necessary but complex phenomenon. In the sections below, we present illustrative data from three salient disagreement practices: focus shift, gaze, and other-initiated turn dependence. Through these examples we demonstrate the complex manner in which participants draw on the interactional resources of multi-party talk to avoid explicit expression of their opposing stance, while at the same time managing good rapport in the group discussion.

\subsection{Focus shift}

The most frequently observed disagreeing practice in the data was labelled a "focus shift". In these instances, a speaker neither explicitly rejects nor accepts his or her interlocutor's previous claim. Rather, the speaker makes a new claim to shift the focus of talk to a claim that $\mathrm{s} / \mathrm{he}$ finds more credible. Focus shifts were often characterised by prefacing ambiguation or were embedded within the disagreement preface "yeah-but" structure (i.e. "partial agreement", a term widely adopted in the literature on disagreement - see: Kreutel, 2007; Locher, 2004; Pomerantz, 1984 referring both to actual partial agreement, but also commonly used as a mitigating device to delay disagreement within a turn or across turns). In this way, the function of the focus shift is to articulate an opposing stance while leaving space for further negotiation. Extract 1, below, provides examples of two different focus shifts (one in line 19 and the other in lines 35-37 and 39-40). The extract is drawn from a section of talk in Group 1's Task A data where the group were considering whether or not they consider British people polite. The main speakers are Haeun (South Korea), Mei (China), Jiro (Japan) and Lexie (Cyprus). 
This example begins with Haeun's statement that service in restaurants in Britain is "very bad", an argument which is developed as Haeun states that British people do not have a "service mind" (lines 10-11). The first disagreement, in the form of a focus shift, occurs in line 19 when Lexie states "it depends on who you come across". Lexie delivers her disagreement by first ambiguating her stance with "it depends". This allows her not to fully reject or contradict Haeun's statement but to draw Haeun, and other group members, onto an alternative claim: that someone might be perceived as impolite if they are having a bad day. The use of ambiguation throughout Lexie's intervention allows her to avoid direct confrontation with Haeun, while at the same time casting doubt on Haeun's stated position.

A second example of focus shift in the same extract begins with Jiro's turn at line 33: "well" (indicating both an alert that Jiro wishes to take the floor and that his response will be dispreferred (Heritage, 2015)). Jiro proceeds to shift focus to the alternative claim that Britain is more polite than other countries (lines 39-40). However, he precedes this counter-claim with a drawn-out "yeah-but" partial agreement structure (lines 36 and 39), conceding initially that Japan is more polite than Britain. It is notable that Jiro's turns are carefully delivered with a repertoire of mitigating devices, e.g., hesitation (through sound lengthening and, particularly, pauses), hedges ("as well" in line 40, "whatever" in line 42) and prefaces ("well" in line 33, "to be honest" in line 36, "I think/thought" in lines 36, 39 and 40 "I found" in line 45). Using a combination of agreement and disagreement and delaying the expression of an opposing stance helps Jiro to attenuate the explicitness of his disagreement throughout this episode of talk (see Pomerantz, 1984).

The use of focus shift plays an important role in multi-party talk by allowing a speaker to articulate an opposing stance without directly attacking his or her interlocutor's idea. The practice thus not only helps sustain group interaction but also - particularly through the additional use of mitigating devices and prefaces - maintains the interactants' interpersonal relationship even within episodes of oppositional talk.

\subsection{Complex turn-management}

Turn-management was another salient feature of disagreement practices in the group discussions. "Turn-waiting" was commonly observed, as in the example above where Jiro allows a disagreement episode to play-out between Haeun and Lexie before making his own claim (line 39). Turn waiting connects with the notion of disagreement as a dispreferred response; one that 
is delayed both within turns and across turns. However, the multi-party interaction enabled two other notable types of turn management pattern: Other-initiated disagreement turn dependence, and turn-throwing/passing.

\subsubsection{Other-initiated disagreement turn dependence}

Other-initiated disagreement turn dependence refers to situations in which participants were able to express disagreement, not by disagreeing with an initial proposition, but by showing agreement with the oppositional stance expressed by another group member. This is illustrated in Figure 1, where P3 disagrees with an initial claim made by P11. This allows Ps 4, 5 and 6 to agree with P3's statement, rather than disagree with Participant 1 directly. This agreement may be expressed through a performative verb (e.g., "I agree with X"), or through the repetition of the linguistic elements, content or underlying intention of a previous dissenting turn. An interaction where there are more than two interactants thus allows speakers to form oppositional alliances (Kangasharju, 2002). Such oppositional alliances confer several advantages to participants: as well as allowing participants to avoid contradicting the initiator of a disagreement source turn, other-initiated turn dependence also legitimises a speaker's opinion as being supported by a larger group. Indeed, by depending on disagreement initiated by others, interactants can prolong or withhold their opposing stance over a series of turns to ensure that an oppositional alliance has been formed, thus minimising the need for direct confrontation.

\section{Figure 1: Other-initiated disagreement turn dependence}

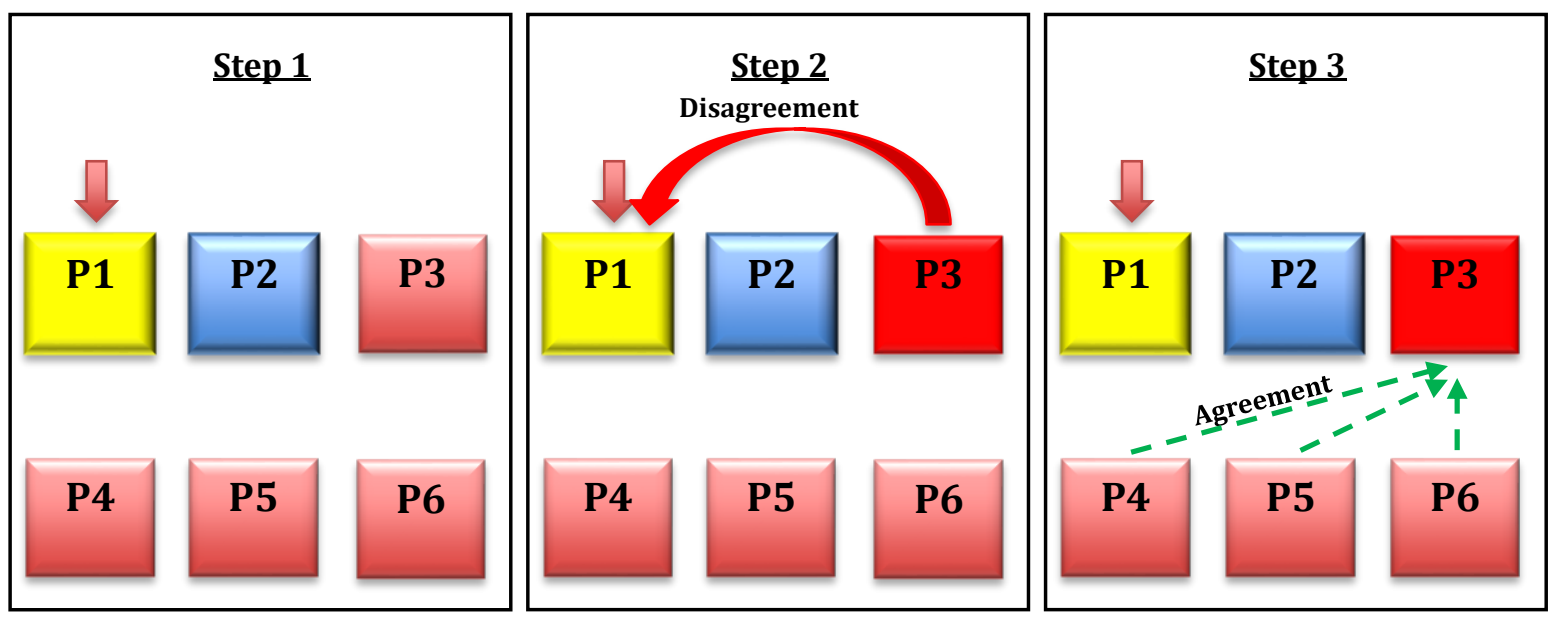

${ }^{1} \mathrm{P}=$ participant in this illustration. 
Extract 2 provides an example of a series of other-initiated disagreement turns. In the extract, Group 1 members (completing Task B) are discussing whether or not they will fund an urgent financial aid project. Lexie supports the project, and provides an extended justification for her decision from lines 1-45. Caroline's use of "But" in line 47 signals that what follows will represent an opposing stance, and in line 49 , she makes an alternative claim that the amount requested for the project would not result in meaningful financial support.

\section{Extract 2: Group 1-Task B (23:33.723-25:30.232)}

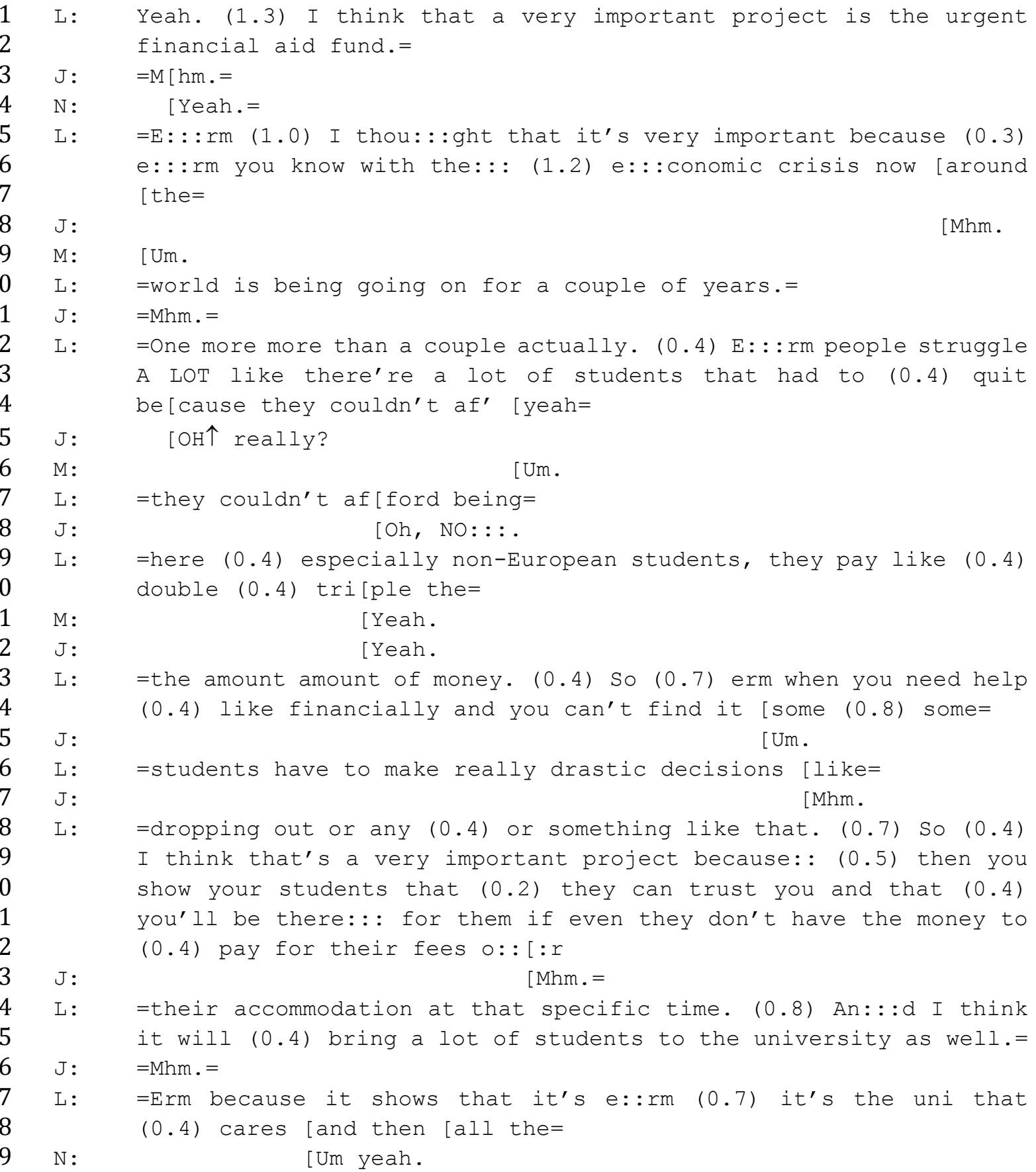




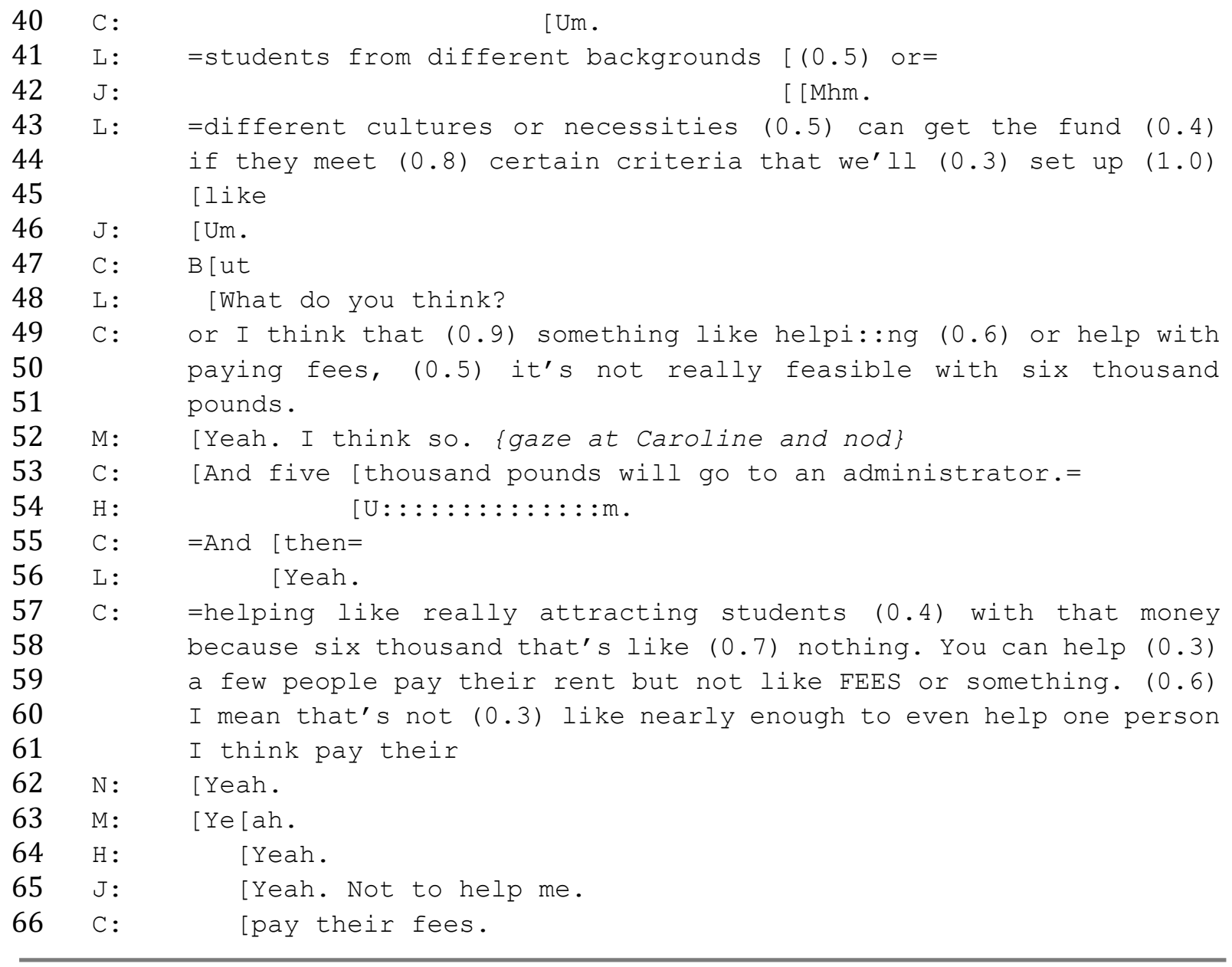

Following Caroline's disagreement turn (lines 47 and 49-51), we can observe a series of turns in which other participants agree with Caroline's position. First, Mei expresses agreement with Caroline's alternative claim by saying "Yeah. I think so" (line 52) together with a direct gaze and head nod towards Caroline. Jiro also clearly agrees with Caroline's positions that the funds are insufficient in line 65: "Yeah. Not to help me". Less overtly, Nourah and Haeun both also appear to express agreement with Caroline through overlapping "yeah" (lines 62 \& 63). Although "yeah" can perform multiple functions in discourse, and is used by various participants as a backchannel throughout Lexie's earlier explication, the stimulated recall data provides evidence that both Nourah [1] and Haeun [2] agreed with Caroline and disagreed with Lexie's position in this case:

[1] I agree with that (the amount of money is not much). [Nourah: G1-TB-stimulated recall interview] 
[2] I was just curious about what is the standard. I mean...what kind of standard can judge the urgent situation or just or just normal situation? And who decides? Because I don't want to express my opinion to unfamiliar group members. Yeah (but I'd do it if I were with close Korean friends). Right. Of course. So later I expressed the ... if some students use this programme in the bad way, and then who knows? But Caroline already talked. The money is just few. I mean it's a small amount of money. So we cannot have the urgent students. [Haeun: G1-TB-stimulated recall interview]

Haeun's metapragmatic comments, in particular, emphasise the usefulness of the other-initiated disagreement turn in a context where group members were relatively unfamiliar and an explicit disagreement may have been too face-threatening. By forming an oppositional alliance with Caroline, Mei, Haeun, Nourah and Jiro are able to distance themselves from confrontation with Lexie.

\subsubsection{Turn-throwing/passing}

A closely linked strategy - used extensively by Jiro (Group 1) - was "turn-throwing/passing", in which a speaker would consciously "throw" their turn to other participants in order to gauge the consensus view and determine whether or not their position would cause offense to others who have not yet spoken. In Extract 3, Group 1 are discussing the relative merits of having one 5000 word coursework assignment per course module versus multiple assignments with lower word counts. Nourah states in lines 1-2 and 4-8 that she does not find a 5000 word assignment manageable without considerable support from her lecturer (here: "doctor"). In response to Nourah's position, Jiro's turn-throwing strategy is evident in lines 11-12, where he asks "I actually want to know how you feel" (and gestures with an open palm towards his interlocutors).

\section{Extract 3: Group 1-Task A (8:37.359-13:35.146)}

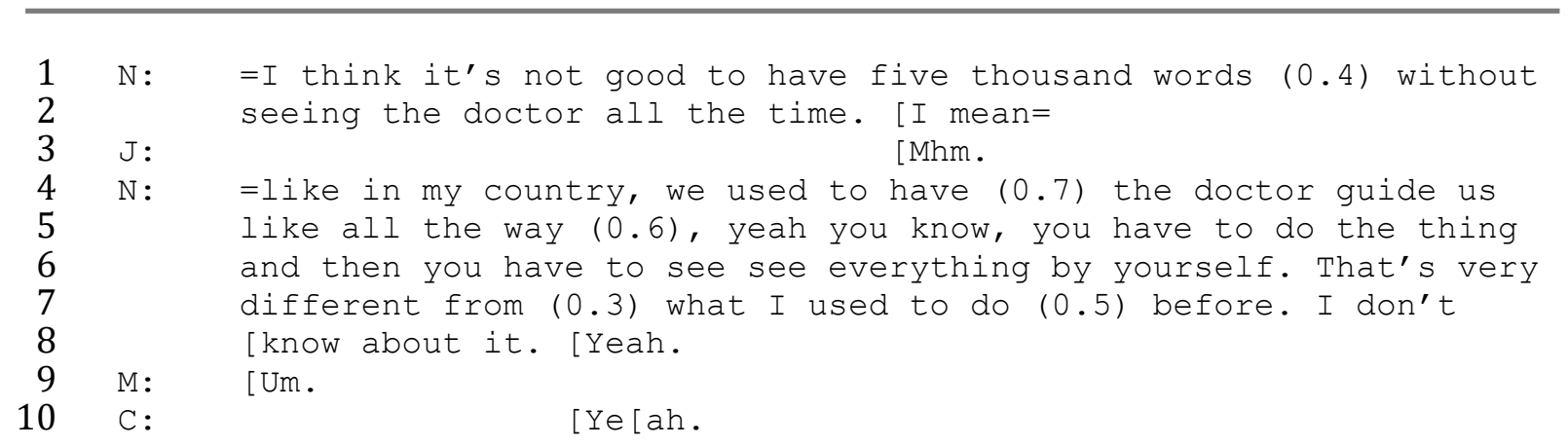




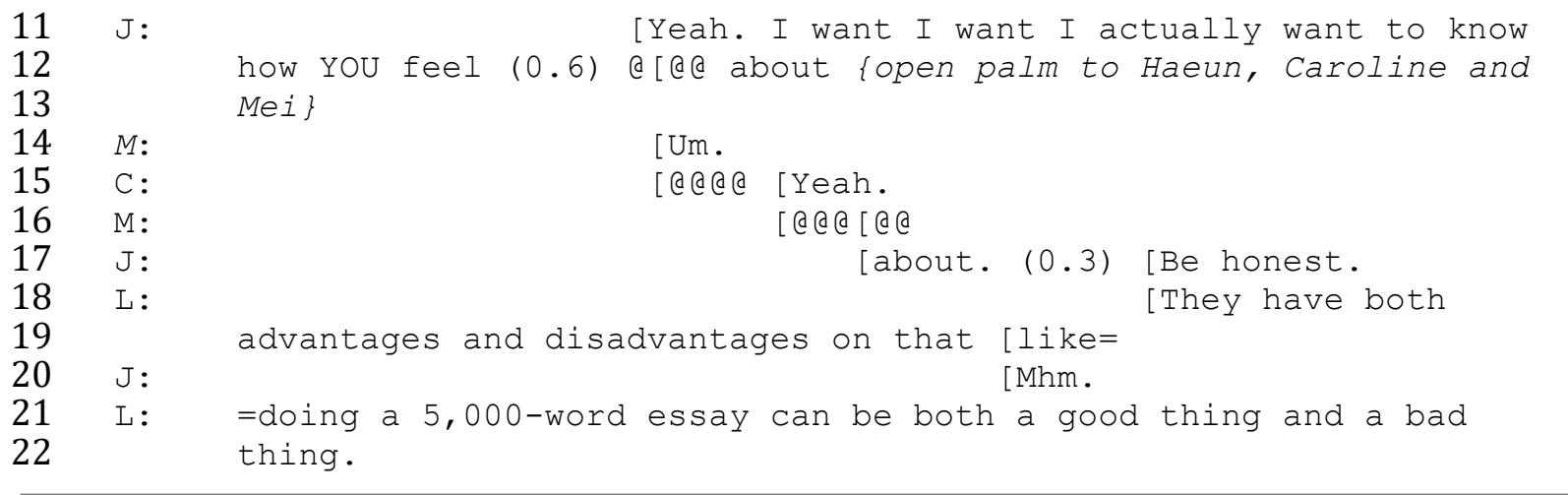

Jiro explains his conscious use of this strategy in the stimulated recall interview, suggesting that turn-throwing is a strategy used to pre-empt disagreement and gauge oppositional alliances within the group:

[3] I was completely for for that [multiple/split assignments]. But the reason I asked was because ... what I might have said was I'd like to have a split so that I can know the process of getting better in a clearer way. But because the others they were not able to experience that process I found it rude to say that explicitly. So I thought I should listen to what they say and adjust it a little bit so that I won't hurt them all or make them feel bad or embarrass them or something like that. [Jiro: G1-TA-stimulated recall interview]

\subsection{Gaze}

As noted in 5.1, participants reported on a range of nonverbal reactions, which functioned to convey disagreement in the group discussion. Using nonverbal expressions enables participants to ambiguate their communicative intents as accurate interpretation of nonverbal responses typically relies on discourse context (Dyne, Ang, \& Botero, 2003; Ochs \& Pelachaud, 2013). Greater ambiguity allows the interactant, once again, to avoid directly confronting an interlocutor. The stimulated recall data in this study allowed for an analysis of nonverbal expressions which were explicitly reported by the participants as being a substitution or a means of showing disagreement. Two instances are shown here, both involving the use of gaze.

In the first instance, Roxane (Group 2) reports on a cut-off gaze (Haddington, 2006) made while another interlocutor - Unyil - was discussing British politeness and indirectness in Task A. At this particular juncture in the discussion, Unyil was attempting to explain his dissatisfaction with feedback he had received on coursework assignments, which he found complicated and inaccurate. Figure 2 illustrates Roxane's eye-gaze throughout this episode. She first rolls her eyes 
(1) and looks around (2) before directing and holding her gaze towards Jimmy (3) who is sitting opposite.

Figure 2: Group 2 members' seating position (Task A) and Roxane's gaze
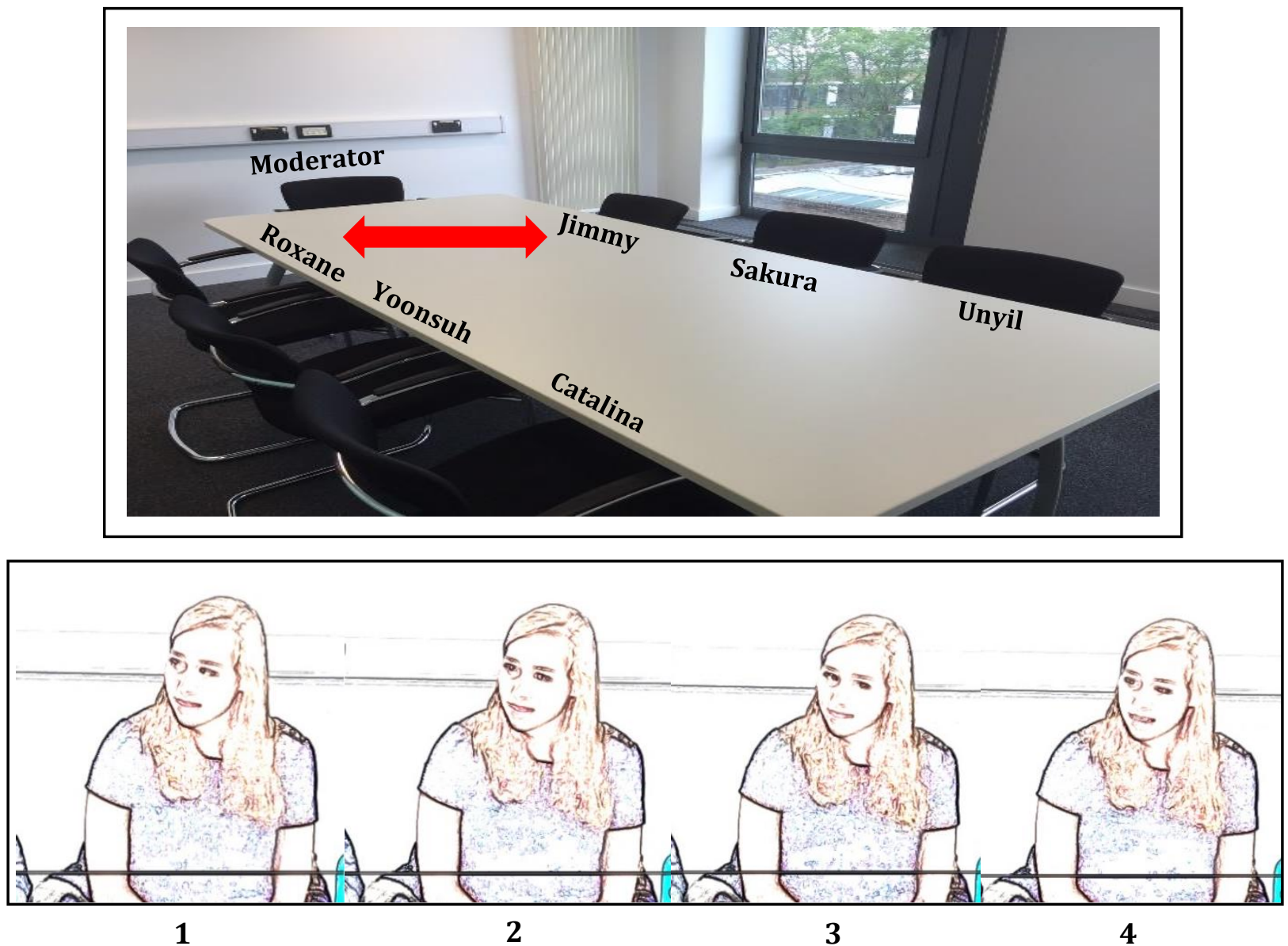

Roxane is silent throughout this exchange, but her eye movements suggest, first, frustration with the direction of conversation, and then an invitation to Jimmy to intervene in some way. Roxane's stimulated recall data [4] provides further evidence that the gaze could be interpreted as a disagreement practice:

[4] I can see myself. I didn't really agree with what Unyil was saying. So I was just sort of like I can see myself sitting there kind of looking down, looking over Jimmy who would be in my sort of on my side and just sort of waiting for someone to maybe disagree with Unyil. I didn't do it myself. But ... to say in certain that thing, but because it's his opinion sort of coming into a culture from a different culture so different experience from mine. So I can't really judge on what his experience is. So just I kind of let what he said stand on its own. (Roxane: G2-TA-stimulated recall interview) 
Roxane clearly disagreed with Unyil's position, but appears to suggest that she did not feel it would be acceptable to explicitly contradict him, particularly on a topic where cultural expectations may differ. She is waiting for an oppositional alliance to form, and is attempting to form this through her gaze with Jimmy. It is less clear from the data whether Jimmy interpreted this practice in the intended way.

Another situation where cut-off gaze use was reported is when Group 2 members were discussing whether or not they would fund a wildlife walks project in Task B. Prior to the gaze instance, Yoonsuh was attempting to convince the group that the project would help improve students' mental health. The first time Yoonsuh raised this point earlier in the discussion, Catalina expressed her disagreement. However, when Yoonsuh raised the point a second time later in the discussion, Catalina said nothing. Rather, Catalina turned her gaze towards Jimmy (sitting opposite) as shown in Figure 3.

Figure 3: Group 2 members' seating position (Task B) and Catalina's gaze
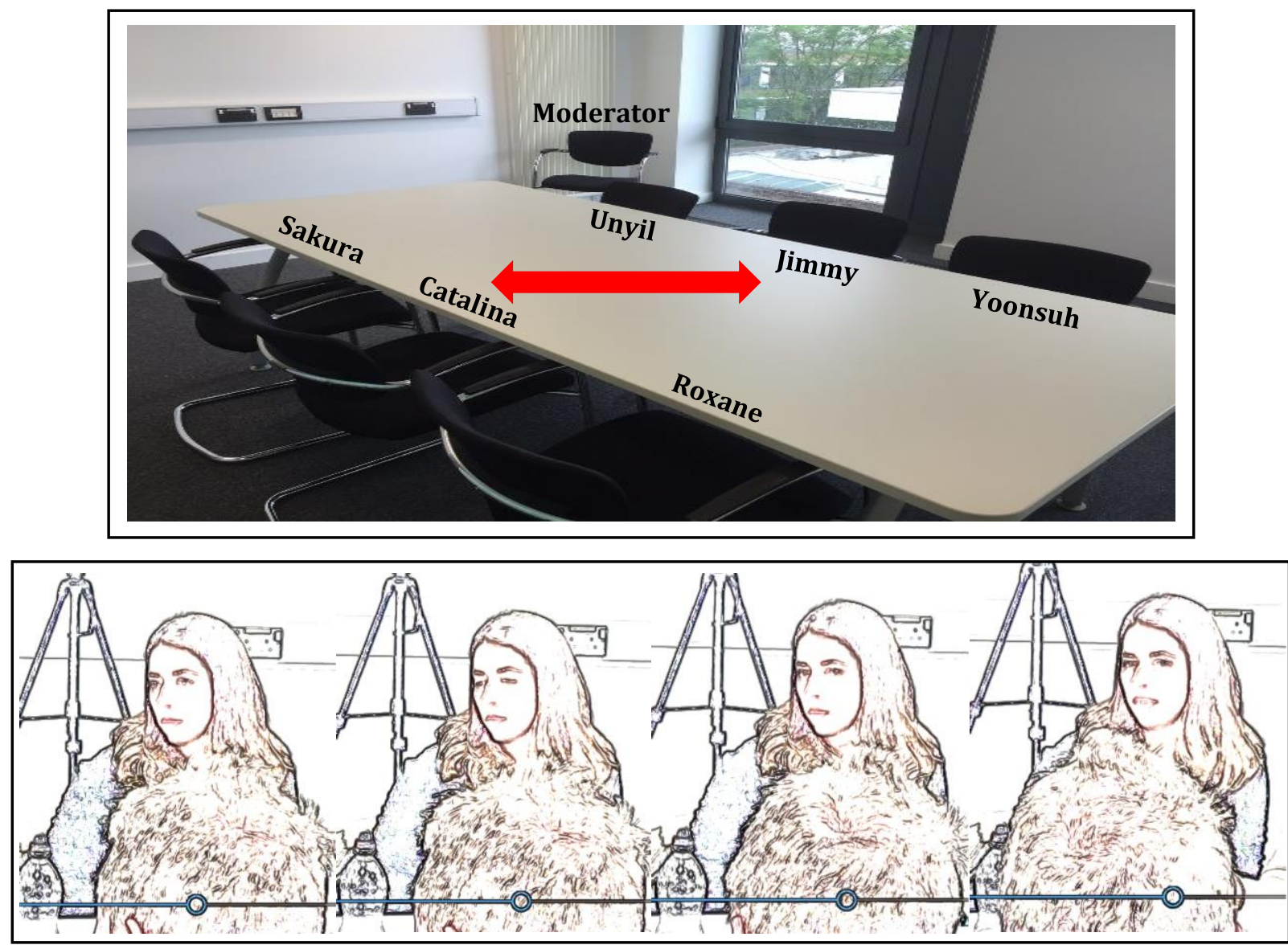
According to her stimulated recall data [5], Catalina knew from Jimmy's brief gaze and laughter that he did not want to fund the project:

[5] Yeah (I looked at Jimmy for a while). We were laughing at her. We were terrible people, I know. No. It's just that... not laughing at her but just laughing about the walk... (long pause) which we think is stupid. Do you understand? Sorry. [Catalina: G2-TB-stimulated recall interview]

Figure [4] provides evidence that Catalina's gaze was registered by Jimmy as he turned away from Yoonsuh (who was sitting directly to his left) (1) and focused his gaze in the direction of Catalina (2 \& 3), before returning his attention to Yoonsuh (4).

\section{Figure 4: Jimmy's responsive actions}

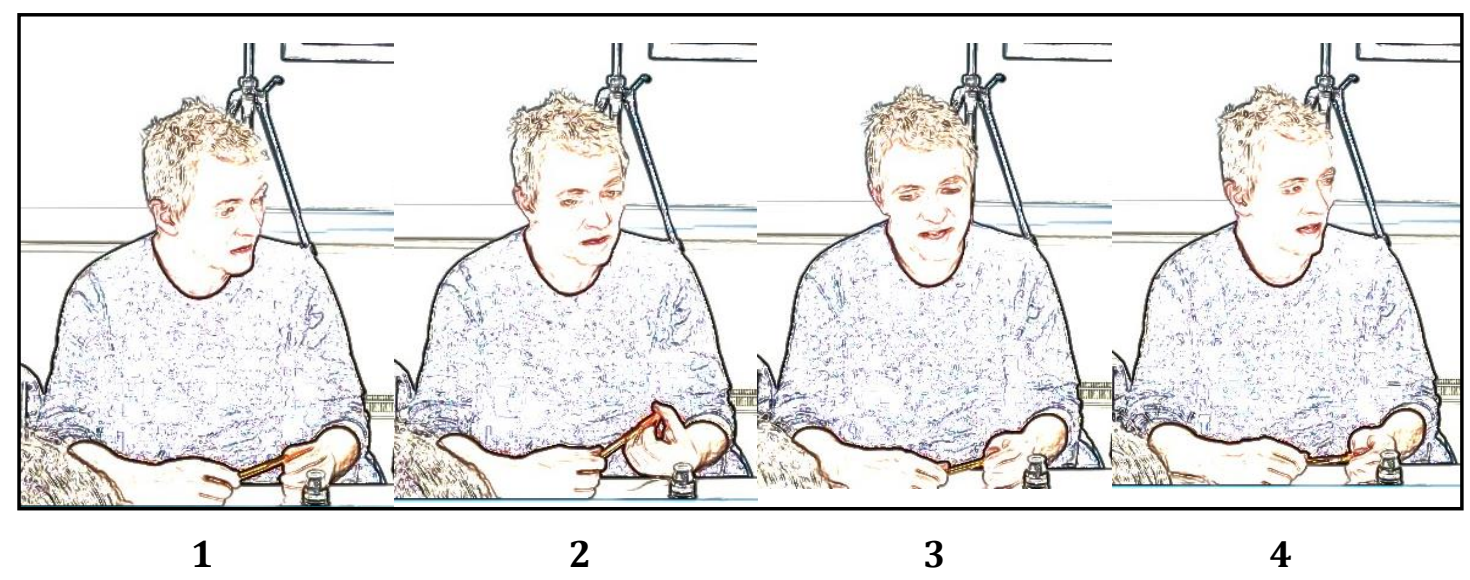

Catalina's gaze at Jimmy therefore seems to serve the function of further solidifying an oppositional alliance to the point under discussion.

\section{Discussion}

This paper has demonstrated, through an analysis of key disagreement episodes drawn from multiple data sources, that while disagreement is prevalent in ELF academic group discussion, it is typically realised through diverse and complex practices designed - in most cases - to minimise confrontation and to avoid explicitness. In this way, the paper both challenges and supports 
previous research on this topic. The ubiquity of disagreement in this study challenges a long-held belief that ELF interactions are inherently supportive and agreement-oriented (Seidlhofer, 2001). Even in Task A, where disagreement was not built-into the task as it was in Task B, disagreement was a salient feature of the interactions. At the same time, ELF participants in the present study can be said to be agreement-oriented in the sense that overt disagreement is clearly a dispreferred activity (cf. Björkman, 2015). Disagreement was rarely expressed directly, and participants tended to favour more complex non-performative, less explicit methods to convey their oppositional stance. These findings contrast with House (2008) who found that ELF speakers used more direct disagreements to achieve functional goals, and Björkman's study (2015) which reveals that when participants prioritise transactional rather than interpersonal goals, or when they are required to demonstrate high-level academic knowledge, they are likely to use explicit disagreement. In this study, we have demonstrated that disagreement in academic group discussion is frequently realised through practices such as ambiguation and partialagreement (reflecting to some extent Bjørge, 2012, and Konakahara, 2016). However disagreement is also realised through non-verbal and interactional strategies such as turnthrowing and other-initiated turn dependence, and through gaze behaviours which function as substitutes for disagreement or as strategies for forming oppositional alliances. These resources comprise a complex repertoire of methods for conveying disagreement within polyadic settings.

The reason for differences in the findings within this study and those in some previous research on academic ELF contexts lies in the notion that ELF communication - like any kind of communication - is intrinsically domain- and context-bound. The very specific characteristics of multi-party academic group discussion are shown here to shape the manner in which disagreement is realised. Amicable and productive disagreement in group discussion requires that interactants can make use of a range of linguistic and contextual resources to achieve both transactional and interactional goals. Particularly, if the ultimate goal of academic group discussion is to work collaboratively in order to complete an assigned task (Bejarano, 1987), employing less explicit disagreement strategies is likely to help establish positive interdependence and active, amicable participation (Ädel, 2011; Topping, 2005). In this study, through the careful selection of disagreeing practices the ELF interactants appear to be aware of linguacultural and interpersonal diversity within the group (Baker, 2017), and consciously monitor and regulate their use of language and their interaction accordingly (Hynninen, 2016). This may be contrasted with the PhD students in Björkman's (2015) study, for example, whose need to establish an identity as in independent scholar drove more direct disagreeing behaviour in one-on-one supervision meetings. Thus, even within the specific academic domain, disagreement in ELF communication is shown to be bound by the goals of the immediate context. 
This study also makes a methodological contribution. To fully understand how relationships are negotiated in lingua franca communication in academic contexts, a more dynamic approach is required which considers the importance of context and values the perspectives of interactants (Nickerson, 2005; Spencer-Oatey, 2000; Zhu, 2015). Given that participants from different cultures may have different linguistic judgments and interactional values, norms and expectancies, there is a particular need for research methods that can tap into metapragmatic reflections, and which do not to over-rely on the researchers' own judgment. Because factors that determine how disagreement is performed can lie beyond the immediate interactional context (Sifianou, 2012), they cannot be revealed by using discourse analysis alone. The incorporation of participants' interactional judgment can also enhance researchers' interpretations (Angouri \& Locher, 2012). This paper therefore represents a useful template for future investigations into ELF interactions in general through the analysis of verbal and nonverbal discourse supported by stimulated recall data.

Finally, the paper makes a contribution to ELF-oriented English for Academic Purposes (EAP) pedagogy. Given that the choices people make in discussion groups can have significant impact on the dynamic of the interaction, for those who prepare students for academic entry in EMI contexts this study underscores the importance of raising awareness of the full range of pragmatic resources - both linguistic and interactional - through which disagreement may be realised. Typical "strategies" which focus on performative disagreement are likely to be less useful for speakers who will need to participate in complex, polyadic discussion tasks.

\section{Future research}

This study raises implications for future research. The methodology presented in this study could be extended to an analysis of recipient's/recipients' behaviour in the next turn. Given that meaning and interpersonal relationships are negotiated between speakers and recipients, it would be important to look at both the disagreement initiator and disagreement recipient's behaviour - both verbal and non-verbal - and the interpretation of this behaviour (e.g., to move beyond intention). Another methodological innovation would be to explore disagreement practices through prolonged engagement in a natural environment, such as a classroom, where the researchers could investigate the development of disagreement practices longitudinally (e.g., as interactants become more familiar with each other over the course of a term/semester). With respect to scope and context, given the present study was looking at disagreement on a very small scale and in a highly contextualised way, future research could be extended to include a larger sample. For example, the categories of disagreement practices and the turn-management 
strategies which emerged within the current study could be used as the basis for a corpus-based study, e.g. with a learner corpus, an ELF corpus or academic discourse corpus. Finally, as the present study focuses on disagreement produced by students pursuing their postgraduate degrees in a UK university, in which the participants were perhaps highly aware of the prevailing British context and its associated norms of politeness, future research could be extended to examine disagreement within EMI academic institutions in non-dominant English speaking contexts. 


\section{References}

Ädel, Annelie. 2011. Rapport building in student group work. Journal of Pragmatics 43. 29322947.

Angouri, Jo. 2012. Managing disagreement in problem solving meeting talk. Journal of Pragmatics 44(12). 1565-1579.

Angouri, Jo \& Miriam Locher. 2012. Theorising disagreement. Journal of Pragmatics 44(12). 1549-1553.

Baker, Will. 2017. English as a lingua franca and intercultural communication. In Jennifer Jenkins, Will Baker \& Martin Dewey (eds.), The Routledge handbook of English as a lingua franca, 25-36. Oxon: Routledge.

Bardovi-Harlig, Kathleen \& Tom Salsbury. 2004. The organization of turns in the disagreements of L2 learners: A longitudinal perspective. In Diana Boxer \& Andrew Cohen (eds.), Studying speaking to inform second language learning, 199-227. Clevedon: Multilingual Matters.

Beccaria, Lisa, Megan Kek, Henk Huijser, Jayln Rose \& Lindy Kimmins. 2014. The interrelationships between student approaches to learning and group work. Nurse Education Today 34. 1094-1103.

Bejarano, Yael. 1987. A Cooperative Small-Group Methodology in the Language Classroom. TESOL Quarterly 21(3). 483-504.

Bjørge, Anne Kari. 2012. Expressing disagreement in ELF business negotiations: Theory and practice. Applied Linguistics 33(4). 406-427.

Bjørge, Anne Kari. 2016. Conflict talk and ELF communities of practice. In Prue Holmes \& Fred Dervin (eds.), The Cultural and Intercultural Dimensions of English as a Lingua Franca, 114133. Bristol: Multilingual Matters.

Björkman, Beyza. 2015. PhD supervisor-PhD student interactions in an English-medium Higher Education (HE) setting: Expressing disagreement. European Journal of Applied Linguistics 3(2). 205-229.

Björkman, Beyza. 2017. PhD supervision meetings in an English as a Lingua Franca (ELF) setting: linguistic competence and content knowledge as neutralizers of institutional and academic power. Journal of English as a Lingua Franca 6(1). 111-139.

Bloom, Benjamin. 1954. The thought processes of students in discussion. In Sidney James French (ed.), Accent on teaching: Experiments in general education, 23-46. New York: Harper. 
Bousmalis, Konstantinos, Marc Mehu \& Maja Pantic. 2013. Towards the automatic detection of spontaneous agreement and disagreement based on nonverbal behaviour: A survey of related cues, databases, and tools. Image and Vision Computing 31(2). 203-221.

Braun, Virginia \& Clarke, Victoria. 2006. Using thematic analysis in psychology. Qualitative Research in Psychology 3(2). 77-101.

Cogo, Alicia. 2010. Strategic use and perceptions of English as a Lingua Franca. Poznań Studies in Contemporary Linguistics 46(3). 295-312.

Dewey, Martin. 2007. English as a lingua franca and globalization: An interconnected perspective. International Journal of Applied Linguistics 17(3). 332-354.

Du Bois, John, Stephan Schuetze-Coburn, Susanna Cumming \& Danae Paolino. 1993. Outline of discourse transcription. In Jane A. Edwards \& Martin D. Lampert (eds.), Talking data: Transcription and coding in discourse research, 45-89. New Jersey: Lawrence Erlbaum Associates.

Dyne, Linn Van, Soon Ang \& Isabel C. Botero. 2003. Conceptualizing employee silence and employee voice as multidimensional constructs. Journal of management studies 40.1359 1392.

Ehrenreich, Susanne. 2017. Community of practice and ELF. In Jennifer Jenkins, Will Baker \& Martin Dewey (eds.), The Routledge handbook of English as a lingua franca, 37-50. Oxon: Routledge.

Firth, Alan. 2009. The lingua franca factor. Intercultural Pragmatics 6(2). 147-170.

Gass, Susan M., \& Alison Mackey. 2000. Stimulated recall methodology in second language research. New Jersey: Lawrence Erlbaum Associates.

Georgakopoulou, Alexandra. 2001. Arguing about the future: On indirect disagreements in conversations. Journal of Pragmatics 33(12). 1881-1900.

Grimshaw, Allen. 1990. Conflict talk: Sociolinguistic investigations in conversations. Cambridge: Cambridge University Press.

Gruber, Helmut. 1998. Disagreeing: Sequential placement and internal structure of disagreements in conflict episodes. Text-Interdisciplinary Journal for the Study of Discourse 18(4). 467-504.

Haddington, Pentti. 2006. The organization of gaze and assessments as resources for stance taking. Text \& Talk 26(3). 281-328. 
Hammer, Mitchell R. 2005. The intercultural conflict style inventory: A conceptual framework and measure of intercultural conflict resolution approaches. International Journal of Intercultural Relations 29(6). 675-695.

Heritage, John. 2015. Well-prefaced turns in English conversation: A conversation analytic perspective. Journal of Pragmatics 88. 88-104.

Honda, Atsuko. 2002. Conflict management in Japanese public affairs talk shows. Journal of Pragmatics 34(5). 573-608.

House, Juliane. 2008. (Im)politeness in English as lingua franca discourse. In Miriam Locher \& Jürg Strässler (eds.), Standard and norms in the English language, 351-366. Berlin: Mouton de Gruyter.

Hynninen, Niina. 2016. Language regulation in English as a lingua franca: Focus on spoken academic discourse. Berlin: De Gruyter Mouton.

Izadi, Ahmad. 2013. Disagreements in Iranian dissertation defenses. Lodz Papers in Pragmatics 9(2). 199-224.

Jenks, Christopher J. 2012. Doing Being Reprehensive: Some Interactional Features of English as a Lingua Franca in a Chat Room. Applied Linguistics 33(4). 386-405.

Jenks, Christopher. 2017. Uncooperative lingua franca encounters. In Jennifer Jenkins, Will Baker \& Martin Dewey (eds.), The Routledge handbook of English as a lingua franca, 279291. Oxon: Routledge.

Jones, Catherine, Michael Connolly, Anthony Gear \& Martin Read. 2006. Collaborative learning with group interactive technology: A case study with postgraduate students. Management learning 37(3). 377-396.

Jones, Jeremy. 1999. From Silence to Talk: Cross-Cultural Ideas on Students Participation in Academic Group Discussion. English for Specific Purposes 18(3). 243-259.

Kakavá, Christina. 1993. Conflicting argumentative strategies in the classroom. In James Alatis (ed.), Strategic Interaction and Language Acquisition: Theory, Practice, and Research, Georgetown University Round Table 1993, 401-420. Washington, DC: Georgetown University Press.

Kakavá, Christina. 2002. Opposition in Modern Greek discourse: cultural and contextual constraints. Journal of Pragmatics 34(10-11). 1537-1568.

Kangasharju, Helena. 2002. Alignment in disagreement: forming oppositional alliances in committee meetings. Journal of Pragmatics 34(10-11). 1447-1471. 
Kappa, Katherine. 2016. Exploring solidarity and consensus in English as a lingua franca interactions. Journal of Pragmatics 95. 16-33.

Kaur, Jagdish. 2009. Pre-empting problems of understanding in English as a lingua franca. In Anna Mauranen \& Elina Ranta (eds.), English as a Lingua Franca: Studies and findings, 107124. Newcastle Upon Tyne: Cambridge Scholars Publishing.

Konakahara. Mayu. 2016. The use of mitigated disagreement in ELF casual conversation: Ensuring mutual understanding by providing correct information. In Kumiko Murata (ed.), Exploring ELF in Japanese academic and business contexts: Conceptualization, research and pedagogic implications, 70-89. New York: Routledge.

Konakahara, Mayu. 2017. Interactional management of face-threatening acts in casual ELF conversation: an analysis of third-party complaint sequences. Journal of English as a Lingua Franca 6(2). 313-343.

Kotthoff, Helga. 1993. Disagreement and concession in disputes: On the context sensitivity of preference structures. Language in Society 22(2). 193-216.

Kreutel, Karen. 2007. “I'm not agree with you.” ESL Learners' Expressions of Disagreement. TESL-EJ 11(3). 1-35.

Leech, Geoffrey. 2014. The pragmatics of politeness. New York: Oxford University Press.

Locher, Miriam A. 2004. Power and politeness in action: Disagreements in oral communication. Berlin: Walter de Gruyter.

Locher, Miriam A. 2006. Polite behavior within relational work: The discursive approach to politeness. Multilingua 25. 249-267.

Locher, Miriam A., \& Richard J. Watts. 2008. Relational work and impoliteness: Negotiating norms of linguistic behaviour. In Derek Bousfield and Miriam A. Locher (eds.), Impoliteness in Language: Studies on its Interplay with Power in Theory and Practice, 77-99. Berlin and New York: Mouton de Gruyter.

Mauranen, Anna. 2012. Exploring ELF: Academic English shaped by non-native speakers. Cambridge: Cambridge University Press.

Muntigl, Peter \& William Turnbull. 1998. Conversational structure and facework in arguing. Journal of Pragmatics 29(3). 225-256.

Nickerson, Catherine. 2005. English as a lingua franca in international business contexts. English for Specific Purposes 24(4). 367-380. 
Ochs, Magalie \& Catherine Pelachaud. 2013. Socially aware virtual characters: The social signal of smiles. IEEE Signal Processing Magazine 30(2). 128-132.

Osvaldsson, Karin. 2004. On laughter and disagreement in multiparty assessment talk. TextInterdisciplinary Journal for the Study of Discourse 24(4). 517-545.

Pietikäinen, Kaisa. 2018. Silence that speaks: The local inferences of withholding a response in intercultural couples' conflicts. Journal of Pragmatics 129. 76-89.

Pomerantz, Anita. 1975. Second assessments: A study of some features of agreements/ disagreements. Ph.D. dissertation. University of California, Irvine.

Pomerantz, Anita. 1984. Agreeing and disagreeing with assessments: Some features of preferred/dispreferred turn shapes. In John Maxwell Atkinson \& John Heritage (eds.), Structures of Social Action: Studies in Conversation Analysis, 57-101. Cambridge: Cambridge University Press.

Rees-Miller, Janie. 2000. Power, severity, and context in disagreement. Journal of Pragmatics 32(8). 1087-1111.

Schegloff, Emanuel. 1968. Sequencing in conversational openings. American anthropologist 70(6), 1075-1095.

Schiffrin, Deborah. 1984. Jewish argument as sociability. Language in Society 13(3). 311-335.

Seidlhofer, Barbara. 2001. Closing the conceptual gap: The case for a description of English as a lingua franca. Annual Review of Applied Linguistics 26. 3-34.

Sifianou, Maria. 2012. Disagreements, face and politeness. Journal of Pragmatics 44(12). 15541564.

Spencer-Oatey, Helen. 2000. Rapport management: a framework for analysis. In Helen SpencerOatey (ed.), Culturally Speaking: Managing rapport through talk across cultures, 11-46. London and New York: Continuum.

Spencer-Oatey, Helen. 2013. Relating at work: Facets, dialectics and face. Journal of Pragmatics 58. 121-137.

Stalpers, Judith. 1995. The expression of disagreement. In Konrad Ehlich \& Johannes Wagner (eds.), The discourse of business negotiation, 275-289. Berlin: Mouton de Gruyter.

Tannen, Deborah. 1984. Conversational style: Analyzing talk among friends. Oxford: Oxford University Press. 
Tannen, Deborah. 2002. Agonism in academic discourse. Journal of Pragmatics 34(10-11). 16511669.

Topping, Keith J. 2005. Trends in Peer Learning. Educational Psychology 25(6). 631-645.

Wisker, Gina, Gillian Robinson \& Miri Shacham. 2007. Postgraduate research success:

Communities of practice involving cohorts, guardian supervisors and online communities. Innovations in Education and Teaching International 44(3). 301-320.

Zhu, Hua. 2015. Negotiation as the way of engagement in intercultural and lingua franca communication: Frames of reference and interculturality. Journal of English as a Lingua Franca 4(1). 63-90. 


\section{Appendix 1: transcription conventions (adapted from Du Bois et al.}

1993)

$\begin{array}{ll}{\left[\begin{array}{ll}\text { [ } \\ =\end{array}\right.} & \text { Overlap } \\ @ @ @ & \text { Cutching } \\ :: . & \text { Laughter } \\ \mathrm{h} & \text { Lengthening sound } \\ \text { CAP } & \text { Audible exhalation } \\ \text { (number) } & \text { Lapsed time/pause in second } \\ \uparrow & \text { Rising intonation } \\ . & \text { An end of an utterance }\end{array}$

Number Line numbers to discuss points of interest

$\{\ldots\} \quad$ Other non-linguistic features (e.g. gestures, facial expressions) 